\title{
New drugs in Brazil: Do they meet Brazilian public health needs?
}

\author{
Carlos Cezar Flores Vidotti, ${ }^{1,2}$ Lia Lusitana Cardozo de Castro, ${ }^{3}$ \\ and Simone Saad Cali ${ }^{4}$
}

Suggested citation Vidotti CCF, Castro LLC, Calil SS. New drugs in Brazil: Do they meet Brazilian public health needs? Rev Panam Salud Publica. 2008;24(1):36-45.

ABSTRACT Objectives. To describe the new drugs marketed in Brazil during the period 2000-2004, compare the description to the country's burden of disease, and suggest initiatives capable of addressing the situation from the perspective of a developing country.

Methods. Records of new drugs were surveyed in an official drug registration database. The new drugs were categorized by Anatomical Therapeutic Chemical classification, indication, and innovation, and compared with the needs of the country's burden of disease. Data on the morbidity and mortality rates of selected diseases (diabetes, Hansen's disease, hypertension, tuberculosis) were retrieved from official documents and the literature.

Results. During the period investigated, 109 new drugs were launched. Most were general anti-infectives for systemic use (19), followed by antineoplastic and immunomodulating agents (16). The number of new drugs launched in 2004 was roughly one-third that of 2000. Of 65 new drugs, only one-third can be classified as innovative. Most new drugs were intended to treat noninfectious diseases that typically affect developed countries, diseases that constitute only a fraction of the country's challenges.

Conclusions. A mismatch occurs between public health needs and the new drugs launched on the Brazilian market. Not only did the number of new drugs decrease in the study period, but only a few were actually new in therapeutic terms. Developing countries must acquire expertise in research and development to strengthen their capacity to innovate and produce the drugs they need.

Key words New drugs, drugs of interest in public health, pharmaceutical drug trade, innovation, pharmacoepidemiology, Brazil.

Brazilian Medicines Information Center (CEBRIM), Federal Council of Pharmacy (CFF). Send correspondence to: Carlos Cezar Flores Vidotti, CEBRIM, Federal Council of Pharmacy (CFF), SBS Q1, Bloco K, Edifício Seguradoras, $8^{\circ}$ andar. Brasília, DF 70093-900, Brazil; telephone: +55 61 33210555; fax: +55 61 3321-0819; e-mail: vidotti@unb. br.

2 Pharmacoepidemiology Research Group of Brasília, Brasília, Brazil.

3 Graduate Program in Health Sciences, School of Health Sciences, University of Brasília (UnB), Brasília, Brazil.

4 Pharmacist, graduate student at the Federal University of Goiás, Goiânia, Brazil.
Research and development (R\&D) are essential to generating health products that combat diseases. R\&D conducted by the pharmaceutical industry addresses the needs of wealthier countries, but all too often, underprivileged populations in poorer areas of the world have few or no treatment options and restricted access to treatments that do exist. The power held by the pharmaceutical industry is, to varying degrees, lost when the market is insufficiently wide or steady, or when effective public policies are not in place to promote R\&D. Given this context, the current situation regarding the launching of new drugs needs to be acknowledged and addressed by policymakers, managers, and researchers in public and private institutions alike, if availability for actual public health needs is to be improved. 
Attendant on Brazil's return to democracy in the 1980s, a new National Constitution came into effect in 1988. It instituted the Brazilian Unified Health Care System (SUS), whose principles, structure, and operation were defined by Laws 8080 and 8142, passed two years later. The system is hierarchically structured and decentralized, and its organization is similar in all three levels of government $(1,2)$.

In Brazil, communicable diseases, which typically constitute a formidable public health challenge in underdeveloped countries, coexist with the chronic diseases common of developed regions. In this phenomenon, termed "epidemiological overlap," rather than undergoing the expected transition experienced by most of the developed countries, morbidity and mortality rates remain high for both groups of diseases, and differences in the epidemiological characteristics of areas within a country, or even across social layers, are heightened $(3,4)$.

In 2004, Brazil's incidence rates for the most common infectious diseases were: malaria (465 657 cases; 100 deaths), dengue (117 519; 8), tuberculosis (80 515; 4 528), Hansen's disease (49 366; 0), and AIDS (30 886; 10 895) (5). Of the noninfectious diseases, systemic arterial hypertension (SAH) had a prevalence of about $22 \%-43 \%$ among urban adult population, depending on the Brazilian city investigated, accounting for at least $40 \%$ of deaths caused by brain stroke (6). Roughly $75 \%$ of these SAH patients depended on the SUS for care (7). With regard to diabetes, in 2005 as many as 11\% of Brazilians 40 years of age and older were estimated to have this diseasei.e., roughly 5.5 million individuals, according to the national statistics agency (8). The association of $\mathrm{SAH}$ and diabetes was responsible for $50 \%$ of cases of terminal renal failure (6).

In 2006, responding to this situation, the Ministry of Health of Brazil launched the National Policy for Primary Care Provision (PNAB). PNAB has targeted the following strategic action areas: the elimination of Hansen's disease and the control of tuberculosis, arterial hypertension, and diabetes mellitus, among others, and made available a fully operational program for AIDS that has now been in place for more than a decade $(9,10)$.

In Brazil, health care funding is mostly provided by the federal government, serving up to $70 \%$ of the population, either directly or in partnerships, while the remaining 30\% are served by private health maintenance organizations (11). All three levels of government are jointly responsible for drug supply. Although the SUS hires private institutions for service provision, including drug supply, related costs are entirely borne by public funds. Access to drugs by way of the SUS has remained at a steady level for over a decade (1991-2004), covering around $20 \%$ of the population $(2,12)$.

The pharmaceutical industry operating in the country has a marked influence on consumption patterns and the shaping of health care policies, including a direct impact on SUS operations (11). The launching of a new prescription product may include sales strategies and techniques that range from sponsoring participation in professional and scientific symposia to offering individual incentives to health professionals; however, prescription drugs cannot be advertised to lay consumers (13); only those drugs intended for self-medication are publicized in mass media (14).

In 1998, the Brazilian National Drug Policy (PNM) was approved. It established, within the scope of its eight guidelines, a list of essential drugs, drug safety regulations, human resource development and capacitybuilding, and scientific and technologic development (15). Approval of the PNM led to a review of the $\mathrm{Na}$ tional List of Essential Drugs in 1999, which had not updated in 16 years, and to subsequent reviews in 2002 and 2006 (16). In 1999, with Law 9782, the National Health Surveillance Agency (ANVISA) was created, with the priority task of implementing the organization of health-related surveillance activities (17). Also in 1999, Law 9787 implemented a policy on generic drugs. In financial terms, the 2003 Brazilian pharmaceutical market was shared among generic drugs, 12\%; patented drugs, 20\%; and similar (nonpatented) drugs at $68 \%$ (18). However, despite its importance, the PNM has not been able to produce R\&D of new drugs within the national health system, missing opportunities such as research of Brazil's biodiversity for pharmaceutical uses (19).

Historically, pharmaceutical corporations operating in Brazil, with either national or transnational capital, have focused largely on manufacturing pharmaceutical products, with very little attention and resources devoted to R\&D of new drugs and formulations $(20,21)$. This picture seems nonetheless to be changing, with an increase in investments and in the involvement of companies in all steps of drug and formulation development. The change is possibly related to the issuing of regulatory standards, improvements in scientific and technological capacitybuilding, favorable economic environment, consolidation of universitybased research and development groups, and better interaction between research groups and pharmaceutical companies (21-24). The year 2004 marked the registration of the first drug developed entirely in Brazil. This new drug was derived from the plant species Cordia verbenacea, whose active principle is alpha-humulene an antiinflammatory $(18,25,26)$.

Governmental support for the pharmaceutical area, in both the public and private sectors, has been growing over the past decade. At the federal level, for instance, it has been provided through the Health Sector Fund, linked to the Ministry of Science and Technology and launched in 1999; the Forum for Competitiveness in the Pharmaceutical Productive Chain, related to the Ministry of Development, Industry, and Foreign Trade and launched in 2003; and the Policy for the Industrial Sector and Foreign Trade (PITCE), designed in 2004. These initiatives have fostered cooperation of their various stakeholders, but so far have not yielded the desired results in terms of research, development, and registration of new drugs for the treatment of prevalent diseases 
(26). In 2003, within the scope of the SUS, the First Brazilian Conference on Drugs and Pharmaceutical Assistance was held (27), approving proposals that support creation of specific public policies on pharmaceutical R\&D in response to health needs and in accordance with epidemiologic and social criteria.

The profile of new drugs launched on the Brazilian market does not reflect the country's specificities (geographical, socioeconomic, epidemiological) or the extent of its pharmaceutical market. This context makes it difficult to ascertain whether new drugs are actually improving treatment for prevalent diseases and for endemic diseases. Also, because achievements in R\&D of substances synthesized or identified in the country are not effectively disseminated, the subsequent steps in drug development fail to be undertaken. Unavailability of such information may delay public policies intended to address the diseases in question.

Trends in registration of drugs approved in the United States of America in 1996, 1997, and 1998 and the different phases of the drug development and approval process have been described by Kaitin and Healy (28). From 1996-1998 as many as 122 new drugs were approved-53, 39, and 30, annually-but only 110 matched the definition of New Chemical Entity (NCE). Of these, 38 (34.5\%) were classified by the United States Food and Drug Administration (FDA) as priority NCEs, meaning they might "be of high therapeutic value," and entitled to priority reviewing. The study focuses on drug development phases without addressing the burden of disease.

Public health needs are another reason to reassess the pharmaceutical market. By doing so, light will be shed on the extent to which the burden of disease is being treated with the drugs currently available, and could aid in identifying gaps, challenges, and opportunities. Trouiller et al. (29) report that as many as 1393 NCEs were granted marketing authorization from 1975-1999, only 16 of which were intended to treat tropical diseases and tuberculosis. Their findings suggest that investment in drug R\&D for neglected diseases is inadequate; for example, "investment for malaria is at least 80 times lower than for HIV/AIDS" (29). Although the pharmaceutical industry has provided drugs for a wide range of disorders, not enough drugs are available to treat tropical diseases.

Descriptions of the pharmaceutical markets in developing countries are rare. Ghosh et al. (30), in an investigation of new drugs introduced in India over a period of 15 years (1988-2002), report that a mean of 26.4 (standard deviation $= \pm 9.52$ ) new products were approved annually. According to the authors, major therapeutic advances are rare, the pharmaceutical market is not needs-oriented, and regulatory structures are not developed to address public health concerns.

Public health interests should drive R\&D of drugs, and a regulatory framework in this context needs to be developed. One potential contribution of such a process is the description of new drugs launched on the pharmaceutical market.

The objectives of this study were to describe new drugs marketed in Brazil during the five years from 2000-2004, compare the description to the country's burden of disease, and suggest initiatives capable of addressing the situation from the perspective of a developing country.

\section{MATERIALS AND METHODS}

We identified new drugs that were approved by the Brazilian National Health Surveillance Agency (ANVISA) in the period 2000-2004 and were granted authorization to be marketed in Brazil. ANVISA is the regulatory authority responsible for the drugs consumed by the Brazilian population. This study did not include drugs for veterinary use, which are registered with a separate regulatory body (the Ministry of Agriculture).

For each of the years investigated, the database Produtos e Registros em Vigilância Sanitária (PRVS ${ }^{\circledR}$, Optionline) was accessed to search for prod- ucts identified by code 175-the one adopted by ANVISA to register new drugs. Diagnostic products, radiological contrasts, vaccines, hemodialysis products, drug combinations, blood derivatives, and immunoglobulins were excluded. The data retrieved were then screened to confirm the year each drug was first marketed, thus excluding drugs registered in previous years.

For the drugs identified, the Anatomical Therapeutic Chemical (ATC) classification (31) and indication were described. A new drug that starts a new ATC level was described as an innovative drug. Innovative features were estimated using the FDA's classification either "priority review" $(\mathrm{P})$ or "standard review" (S). 'P' designates "significant improvement compared to marketed products in the treatment, diagnosis, or prevention of a disease," whereas ' $S$ ' applies to products that do not qualify for priority reviewing (32).

Information on the most prevalent diseases in Brazil was obtained from Datasus (33), the official information system of SUS, and from documents related to the PNAB (6-9, 16, 34-36).

\section{RESULTS}

The study identified 109 new drugs during 2000-2004, the period investigated: $37(33.9 \%)$ in 2000; $22(20.2 \%)$ in $2001 ; 26(23.9 \%)$ in $2002 ; 13(11.9 \%)$ in 2003; and $11(10.1 \%)$ in 2004, with a mean of $21.8 \pm 10.5$ new drugs per year. Figure 1 shows the distribution of their therapeutic uses, categorized according to first-tier ATC codes, either officially assigned (31) or unofficially assigned by the authors. The anatomical groups containing over $10 \%$ of new drugs were J (general antiinfectives for systemic use), with 19 (17.4\%); L (antineoplastic and immunomodulating agents); with 16 $(14.7 \%)$ and $\mathrm{G}$ (genitourinary and sex hormones), with 13 (11.9\%).

For drugs classified in more than one category, only the classification deemed by the authors to be the "main" classification was taken into account. 
FIGURE 1. Major Anatomical Therapeutic Chemical (ATC) groups of new drugs launched in Brazil in the period 2000-2004 $(n=109)$

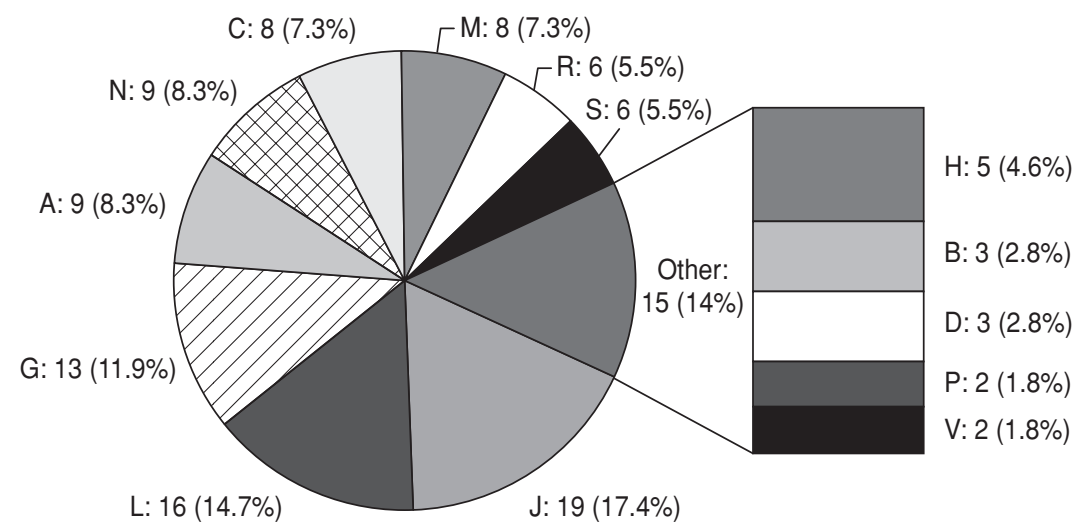

\begin{abstract}
A - Alimentary tract and metabolism
B - Blood and blood-forming organs

C - Cardiovascular system

D - Dermatologicals

G - Genitourinary system and sex hormones

$\mathrm{H}$ - Systemic hormonal preparations, excl. sex hormones and insulins

$\mathrm{J}$ - Antiinfectives for systemic use
\end{abstract}

\author{
L - Antineoplastic and immunomodulating \\ agents \\ $\mathrm{M}$ - Musculoskeletal system \\ $\mathrm{N}$ - Nervous system \\ P - Antiparasitic products, insecticides, \\ and repellents \\ R - Respiratory system \\ S - Sensory organs \\ V - Various
}

This was the case with sodium colistimethate (originally classified as both A and J, but assigned by the authors to category J), dimentidene (originally $\mathrm{D}$ and $R$, assigned to $R$ ), flutrimazole (originally D and $G$, assigned to $G$ ), and eflornithine hydrochloride (originally $D$ and $P$, assigned to $P$ ).

Table 1 shows the new drugs approved each year, distributed according to the FDA classification as Priority $(\mathrm{P})$ or Standard $(\mathrm{S})$, here considered as innovation-like criteria. Of the 109 new drugs, 65 (59.6\%) were listed in the FDA website (32) and nearly onethird were classified as 'P.' The table also shows the distribution of new drugs registered for treatment of the diseases regarded as strategic by the Health Ministry-Hansen's disease, tuberculosis, diabetes, and hypertension. Less than $10 \%(8 / 109)$ of the new drugs are targeted to treat them.

In 1998, cardiovascular diseases were the first cause of death in Brazil, with 381202 cases, and the second in morbidity and mortality (23). Eight $(7.3 \%)$ drugs were registered to treat cardiovascular conditions: bosentan
(C02KX01), barnidipine (C08CA12), midodrine (C01CA17), dofetilide (C01BD04), ezetimibe (C10AX09), levosimendan (C01CX08), olmesartan medoxomil (C09CA08), and rosuvastatin (C10AA07). Three (2.7\%) new drugs-barnidipine, bosentan, and olmesartan medoxomil-for treatment of hypertension were introduced during this period (Table 1).

Cancer was the second cause of death, with 153449 cases in 1998, and the seventh in morbidity and mortality (23). Eight (7.3\%) new drugs were introduced: exemestane (L02BG06), fulvestrant (not yet classified), gentuzumabe ozogamicin (not yet classified), infliximab (L04AA12), immunocyanin (L03AX10), imatinib (L01XX28), pemetrexede (L01BA04), and temozolomide (L01AX03).

Infectious and parasitic diseases were the third cause of death, with 83791 cases in 1998, and also the third cause of morbidity and mortality (23). In 2004, tuberculosis accounted for 4528 officially-reported deaths (25). Two $(1.8 \%)$ new drugs for treating tuberculosis were identified in our sur- vey: rifapentine (J04AB05) and terizidone (J04AK03) (Table 1). Neither was selected for inclusion in the $\mathrm{Na}$ tional Essential Drug List (RENAME 2006) (16), but terizidone is included in the list of drugs adopted by the Ministry of Health for treatment of multidrug-resistant tuberculosis. Two other drugs $(1.8 \%)$ for parasitic diseases were registered. The first to reach the market was eflornithine (P01CX03), indicated for treatment of the meningoencephalitic stage of Trypanosoma brucei gambiense infection (West African sleeping sickness), but introduced in Brazil to reduce undesired facial hair in women, thus denoting a lifestyle use. The second was nitazoxanide, used in the treatment of diarrhea and intestinal parasitic infections.

The introduction of new drugs for tuberculosis, Hansen's disease, and hypertension (three of the four diseases of strategic importance in the National Policy for Primary Care) has already been addressed in the previous paragraphs. Four drugs (3.7\%) for the treatment of diabetes (the fourth 
disease in this group) were registered in the period of study: pioglitazone hydrochloride (A10BG03), rosiglitazone maleate (A10BG02), nateglinide (A10BX03), and voglibose (A10BF03).

\section{DISCUSSION}

From 2000-2004, the number of new drugs registered dropped to approximately one-third. The trend is global $(37,38)$, as nearly all innovative pharmaceutical companies producing and/or marketing drugs in Brazil are based in developed countries (39).

Comparison of data from Brazil and India (30), another developing country, showed that the mean number $( \pm$ SD) of new drugs introduced each year was roughly the same: 22.0 $( \pm 10.5)$ and $26.4( \pm 9.5)$, respectively. In India, however, an increase was found in the last two years in the period, in contrast with the decrease observed in Brazil and the United States (10). Ghosh et al. (30) claim that "Indian companies probably want to bring in as many new molecules into the market before WTO-TRIPS cut-off date of January 2005." This behavior shows an imbalance between market strategies and the burden of disease as forces that push for new drugs. Our results revealed that, similarly to the United States and Europe, registration of new drugs decreased in Brazil (37, 38). FDA's report "Innovation and Stagnation" (37) provides an "analysis of the pipeline problem-the recent slowdown, instead of the expected acceleration, in innovative medical therapies reaching patients." In others words, despite the huge amount of new knowledge available in the basic sciences-particularly in genomics and biotechnology, and secondarily, in the revolution of information and communication technology - the pharmaceutical development process has not been able to take advantage of these achievements. According to the report, the age of drugs based on human genomics is yet to come.

Three areas of challenge were identified: the first one addresses transforming new basic-science knowledge into potential new drugs; the second involves making the drug development process faster, less costly, and more reliable than the one that has been in place for decades; and the third relates to prioritizing and funding R\&D of untreated and/or not properly treated diseases $(29,37,40)$. The argument that the development process is already some decades old, dating back to a time when the current advances were quite unimaginable, is valid if one considers its limited capability for predicting failures before human testing was available. Human testing now accounts for rejection of $92 \%$ of potential new drugs. Many years after drug discovery or synthesis, and after years of pre-clinical tests, only $8 \%$ of substances entering Phase I clinical trials reach the market as new drugs (37). On the other hand, the fast track on drug approval has been causing considerable harm to consumers, making them lose confidence in health authorities $(41,42)$.

Distribution into ATC groups (Figure 1) shows that four groups alone account for as many as $53.6 \%$ of new registered drugs in Brazil: 'antiinfectives for systemic use' (J, 17.3\%), 'antineoplastic and immunomodulating agents' (L, 14.5\%), 'genitourinary system and sex hormones' (G, 10.9\%), and 'nervous system' (N, 10.9\%). Tuberculosis, Hansen's disease, hypertension, and diabetes are priorities in primary care in Brazil (9), and drugs to treat them are included in groups J, C, and A. The small number of new drugs in these groups, and the absence of any new drug for Hansen's disease, contrasts with the magnitude of the disease burden, pointing to the need for improving research, development, and marketing of these products, processes that are overinfluenced by economic power.

Antiinfectives for systemic use (J) was the group with the most newly registered drugs (19, or $17.3 \%$ ) (Figure 1), and a proportion similar to that of India (15.4\%) (30). In this group, 10 systemic antibacterials (J01) and five systemic antivirals (J05) were registered in Brazil, although antiviral drugs, which account for only $4.6 \%$ of the total and $26.3 \%$ of drugs in group J, are essential in the treatment of AIDS, of which 30886 new cases and 10895 were reported in the country in 2004 (43). The disease burden, along with the level of effectiveness of organized groups $(10,26)$, are reflected in the priority assigned by the National STDAIDS Program to drug availability. In 2002, the Ministry of Health of Brazil allocated 516 million reals (US\$ 190 million) to the purchase of antiretroviral drugs (44). These factors might explain the number of new registered drugs.

On the other hand, also in group J, only two $(0.2 \%)$ new drugs for tuberculosis were registered-rifapentine (J04AB05) and terizidone (J04AK03) neither of them selected for inclusion in RENAME 2006 (16), although terizidone is included in the list of drugs adopted by the Ministry of Health for treatment of multidrug-resistant tuberculosis (45). In Brazil, however, as many as 80515 cases of tuberculosis were reported in 2004, with an expected underreporting rate of $30 \%$ (46) and 4528 deaths in the same year. In a county in northeastern Brazil the cost of treatment of each new case was approximately US\$103, but 27 times higher for treatment of multidrugresistant tuberculosis. The disease incurs expenses of approximately 33\% of the patient's family income; and of the public health care services' expenditure on tuberculosis, up to $65 \%$ is required for hospitalizations and $32 \%$ for treatment, with only $3 \%$ being left for prevention (47). These costs have been estimated to be enough to fund R\&D of a new drug for tuberculosis (26).

As for Hansen's disease, 49366 new cases were reported in Brazil in 2004 (43). No new drug, however, was registered for its treatment. Despite the effectiveness of the recommended treatment with rifampicin, dapsone, and clofazimine (35), high dropout rates have been observed due to the lengthy duration of treatment-up to 12 months (46).

In groups $\mathrm{L}, \mathrm{G}, \mathrm{A}, \mathrm{N}$, and $\mathrm{C}$, which account for $16(14.7 \%), 13(11.9 \%), 9$ $(8.2 \%), 9(8.2 \%)$, and $8(7.3 \%)$ of the new drugs, respectively, the balance be- 
tween disease burden and the new drug introduction has been questioned. Neuropsychiatric diseases are in the forefront of the disease burden in Brazil, accounting for $18.6 \%$ of disabilityadjusted life years (DALY) (4), but group $\mathrm{N}$ was second in number of new drugs launched. Cardiovascular diseases, the second most important in terms of DALY (13.3\%), was third in number of new drugs launched, and only three new products $(37.5 \%$ of group $\mathrm{C}$ and $2.7 \%$ overall) were targeted to treat hypertension (Table 1). Six drugs for cancer were registered in the period, accounting for $37.5 \%$ of group L (antineoplastic agents), the largest group. Cancer, having caused 153449 deaths in 1998, was responsible for the seventh highest disease burden in the country in that year (4). In 2002 the Brazilian federal government spent 1183 million reals (US\$ 435 million at the time) in cancer chemotherapy (44). In the alimentary tract and metabolism (A) group, nine drugs $(8.2 \%)$ were launched, three of them for diabetes (2.7\% of the total and $33.3 \%$ of the drugs in group A) (Table 1). In Brazil, the disease burden resulting from diabetes was calculated as $5.5 \%$ of DALY (4), or the fourth cause $(7.2 \%$ of the total) of years lived with disability (YLD).

In group $G$ (genitourinary system and sex hormones), three new drugs for treatment of erectile dysfunction were launched: apomorphine hydrochloride, tadalafil, and vardenafil hydrochloride, all of them lifestyle drugs. This was also the case with the two new drugs $(1.8 \%)$ registered in group P (antiparasitic products, insecticides, and repellents): eflornithine hydrochloride, classified both in groups $\mathrm{P}$ and D (dermatologicals), and nitazoxanide, for the treatment of amoebiasis. Eflornithine, however, though indicated for treatment of African trypanosomiasis, which does not occur in Brazil, was registered in Brazil as a drug for reduction of undesired facial hair in women, configuring lifestyle use for a drug originally intended to treat a neglected infectious disease, thus distorting the purpose of R\&D of drugs and formulations for health treatment.
The launch of new drugs has a strong commercial component, and disease burden is only one element in the range of determinants that trigger the process of research and development of new pharmaceutical products. An influential element is private consumption, as shown by the fact that $60 \%-70 \%$ of Brazilians purchase drugs at private pharmacies and 35\% (the wealthier segment of the population) are covered by private medical plans, a feature that may define the target public for new pharmaceutical products (2, 12). In ATC groups where some degree of balance can be found between disease burden and launch of new drugs, products are largely targeted to consumers with higher purchasing power, in spite of the low degree of therapeutic innovation (Table 1).

Because of the demands for treatment of musculoskeletal diseases, which account for 5.5\% of DALY (4), and the potential purchasing power of patients, safety requirements can be overlooked. These diseases are primarily treated with group M drugs, eight $(7.3 \%)$ of which were launched in study period, including all four antiinflamatories of the coxib class: etoricoxib (M01AH05), lumiracoxib (M01AH06), parecoxib (M01AH04), and valdecoxib (M01AH03). None of these was selected for inclusion in RENAME 2006 (16) and their release in the market has been targeted to private consumers, who are at the mercy of potential inabilities of pharmacovigilance services to provide early detection of safety issues, as illustrated by events involving rofecoxib and lumiracoxib. Rofecoxib, introduced in Brazil in 1999 (26) was globally withdrawn in 2004 following deaths resulting from an increase in cardiovascular episodes, such as heart attacks and strokes, in patients treated for more than 18 months. In Brazil, marketing of the drug was unilaterally discontinued by the manufacturers, though ANVISA had not been notified of any serious suspected adverse drug reactions in cardiovascular events (48). The same pattern has been occurring with luminacoxib, with lawsuits in several countries and discontinuation of marketing, given the occurrence of liver disorders. In Brazil, only the pharmacovigilance system of the state of São Paulo has reported similar cases. These facts probably reflect the still incipient condition of pharmacovigilance systems in Brazil. Drug safety, therefore, is still an issue not dealt with satisfactorily, either by pharmaceutical companies or health authorities. A new framework is needed to provide new drugs of public health interest that can prove safe, effective, and affordable.

The range of strategies, including drug therapy, available to treat diseases, can attest to the pharmaceutical industry's inability to or lack of interest in producing new drugs that fully address public health needs, demographic changes, and disease patterns. The World Health Organization (WHO) (38) has proposed measures to overcome those limitations, including public-private partnerships (PPPs) and reduction of barriers to developing and licensing new drugs.

PPPs may configure an effort to provide new drugs to treat neglected diseases in a scenario of absence of interest from private companies. One example is the discovery by the US Walter Reed Army Institute of Research of the antimalarial drug mefloquine, later developed in partnership between a pharmaceutical company and the Special Program for Research and Training in Tropical Diseases, jointly developed by the United Nations Development Program, the World Bank, and WHO (49, 50). Nonetheless, hope in PPPs should be balanced with a close follow-up of their projects and the results achieved, particularly for very neglected diseases, such as leishmaniasis, where the public sector should be in the lead (29).

Reducing the barriers to innovation is an endeavor that will inevitably face safety issues that have led users to lose trust in health authorities. Moreover, lack of innovation may result from emphasis being placed-by manufacturers and governments alike, in an attempt to improve commercial balances-on market competition rather than on public health concerns (40-42). 
TABLE 1. New drugs approved for use in Brazil from 2000-2004, by year and FDA classification, and number of new drugs intended for priority diseases

\begin{tabular}{|c|c|c|c|c|c|c|c|c|c|c|c|}
\hline \multirow[b]{3}{*}{ Year } & \multicolumn{4}{|c|}{ New drugs (FDA innovation criteria) } & \multirow[b]{3}{*}{ Total } & \multirow{3}{*}{$\begin{array}{c}P \\
\text { rate } \\
(\%)\end{array}$} & \multicolumn{4}{|c|}{ New drugs } & \multirow{3}{*}{ Total } \\
\hline & \multicolumn{2}{|l|}{ Priority $(\mathrm{P})$} & \multicolumn{2}{|l|}{ Standard (S) } & & & \multicolumn{3}{|c|}{$\begin{array}{c}\text { Intended for } \\
\text { priority diseases }\end{array}$} & \multirow{2}{*}{$\begin{array}{l}\text { Intended } \\
\text { for other } \\
\text { uses }\end{array}$} & \\
\hline & Drug name & $n$ & Drug name & $\bar{n}$ & & & $\mathrm{DI}$ & $\mathrm{AH}$ & $\mathrm{HD}$ & & \\
\hline 2000 & $\begin{array}{l}\text { Alosetron, dalfopristin }{ }^{\mathrm{b}} \text { linezolid, lopinavir, } \\
\text { nitazoxanide, oseltamivir, pioglitazone, } \\
\text { temozolomide, verteporfin, zanamivir, } \\
\text { zoledronic acid }\end{array}$ & 11 & $\begin{array}{l}\text { Balsalazide, cetrorelix, dexmedetomidine, } \\
\text { dofetilide, eletriptan, esomeprazole, } \\
\text { etonogestrel, exemestane loteprednol, } \\
\text { memantine, moxifloxacin, nateglinide, } \\
\text { rosiglitazone, sirolimus, zaleplon }\end{array}$ & 15 & 26 & 42.3 & $3^{f}$ & & $2^{\mathrm{h}}$ & 32 & 37 \\
\hline 2001 & $\begin{array}{l}\text { Bimatoprost, caspofungin, ganirelix, } \\
\text { gemtuzumabc, imatinib, ozogamicin }{ }^{c}, \\
\text { travoprost }\end{array}$ & 7 & $\begin{array}{l}\text { Apomorphine, desloratadine }{ }^{d} \text {, } \\
\text { drospirenone, eflornithine, ertapenem, } \\
\text { lutropin alfa, peginterferon alfa-2 } a^{e} \text {, } \\
\text { telithromycin }\end{array}$ & 8 & 15 & 46.7 & & $1^{g}$ & & 21 & 22 \\
\hline 2002 & Fondaparinux, tegaserod & 2 & $\begin{array}{l}\text { Aminolevulinic acid, cilostazol, } \\
\text { choriogonadotropin alfa, escitalopram, } \\
\text { paricalcitol, pimecrolimus, sevelamer, } \\
\text { tiotropium, valdecoxib, voriconazole }\end{array}$ & 10 & 12 & 16.7 & & & & 26 & 26 \\
\hline 2004 & Enfuvirtide & 1 & Duloxetine, dutasteride, rosuvastatin & 3 & 4 & 25.0 & & $2^{\mathrm{g}}$ & & 11 & 11 \\
\hline Total & & 22 & & 43 & 65 & 33.8 & 3 & 3 & 2 & 101 & 109 \\
\hline
\end{tabular}

\section{Inequity and drug policies}

Table 1 reveals that most new drugs fit into the "me-too" type, since as few as $33.8 \%$ are classified under the 'Priority' (P) heading. Furthermore, new drugs are introduced at an ever lower rate, and public health needs are only partially met. The patent system has not been working as claimed-i.e., to ensure true innovation in accordance with the concept of therapeutic innovation (51) - and a new framework is needed if current health problems are to be overcome $(10,52)$.

The case of lifestyle drugs such as tadalafil and vardernafil, both registered in the period of this study, delineates a new scenario in the pharmaceutical market, with companies focusing R\&D on profitable products not exactly intended to treat diseases but regular human conditions instead (such as impotence, baldness, and aging). This focus unduly drains attention, efforts in R\&D, and funding, while public health needs are overlooked. For example, malaria and Chagas' disease, considered neglected diseases, have not benefited from new treatment options in terms of NCEs since 1997 and 1984, respectively (53). A gap still remains in studies on the impact that this behavior of pharmaceutical industries has on public health.

The burden of disease lags behind, still to be treated, while the country's health and socioeconomic aspects have not improved as fast as they might, or have even worsened $(26,54)$.

The Brazilian government, at all its levels-federal, state, and municipalpurchases $35 \%$ of the entire national pharmaceutical production (55) and is the main buyer in this sector, having spent roughly US $\$ 2.1$ billion on drugs in 2004. The government should thus develop initiatives, or improve existing ones, that focus on diseases of greater impact on public health, ones that consequently have a negative socioeconomic influence. The government, after all, has the legal duty, power, financial resources, and development-oriented interest to design and implement public policies to foster the availability of new and improved drugs for the treatment of diseases that affect the population.

\section{Innovation pitfalls}

Table 1 shows an average priority $(\mathrm{P})$ rate of $33.8 \%$, a finding similar to that of a study conducted in Europe and the United States (29) that detected an average innovation index of 0.313 in the period 1975-1999, based on an av- 
erage of 55.7 NCEs introduced each year. Table 1 also shows that the $P$ rate is decreasing, configuring two groups: the mean for 2000-2001 was $44.5 \%$; that for 2002-2004 was as low as $18.0 \%$ in sharp contrast with the levels expected for new drugs. The degree of innovation of these new drugs is also reflected in their therapeutic classification, as only six (5.5\%) started a new ATC therapeutic group: alosetron (A03AE01), memantine (N06DX01), zanamivir (J05AH01), atosiban (G02CX01), sodium colistimethate (A07AA10, J01XB01), and bosentan (C02KX01). Three of them were introduced in 2000, but none was in 2004. As with the slowdown in NCEs, there is a worldwide concern about the low level of innovation. Of the 110 drugs approved in the United States from 1996 to 1998, $72(65.5 \%)$ were marked as Standard NCEs (28). In India, major therapeutic advances are rare and some products are mere stereoisomers of already existing molecules, few of which offer substantial advantages over racemates that have long been available (30).

None of the new drugs was selected for inclusion in RENAME 2006 (16), a list that favors drugs whose patents have already expired. It can be inferred that those new drugs did not have enough therapeutic innovation to overcome this rule.

\section{Meeting the burden of disease}

In Brazil, eight new drugs (7.3\%) were introduced to treat the diseases targeted by the National Policy for Primary Care. Six (75\%) were intended for noninfectious diseases (hypertension and diabetes) and two (25\%) for tuberculosis, but no new drugs for Hansen's disease were introduced (Table 1). In 1999, the five leading causes of death in Brazil were (in decreasing order) cardiovascular diseases, cancer, infectious and parasitic diseases, chronic respiratory diseases, and perinatal problems (4). Specific drugs are needed to treat these conditions, but the majority of new drugs available are meant for cardiovascular diseases and other conditions that typically affect developed countries. With regard to infectious and parasitic diseases, only rifapentine and terizodone are specific for tuberculosis. A large gap exists between the burden of disease and investments in R\&D and innovation; "market forces" are not powerful enough to ensure the development of drugs to treat diseases that affect the poor, who usually cannot afford treatment (56).

\section{Health priorities and networks}

In this scenario, the public sector of developing countries has a role to play that differs considerably from that of wealthier countries. In the former, most health research and some manufacturing is funded by and conducted within the public sector, and therefore, must be driven by public health needs $(55,57,58)$.

The Brazilian Conference on Science and Technology in Health was held in 2004 with the primary purpose of creating an agenda of needs-driven research and development in health. Its report set priorities to tackle health issues, thus representing a shift in the way these have been dealt with, strengthening or creating networks capable of improving capacity and technology sharing, avoiding duplicate efforts, targeting similar outcomes, and leading to an effective management and exchange of information, in order to reach results faster and less cost-effectively.

Capacity strengthening and better use of scarce funding have been implemented by international networks that bring together public and private institutions in developing countries, helping them to address the burden of disease that affects their populations and improving R\&D and innovation, as well as economy and health. Examples of such initiatives include the SouthSouth Initiative in Tropical Disease Research, congregating research groups from Latin America, Asia, and Africa, and the India-Brazil-South Africa Dialogue Forum, which focuses on intellectual property and access to drugs, traditional medicine, and R\&D of vaccines and pharmaceutical products to address national priorities (57).

\section{CONCLUSION}

This study was based on secondary sources of information that may compromise the description of the new drug environment and disease burden in Brazil. Also, the study focused on those drug groups with higher numbers of new drugs and on the diseases viewed as priorities for primary care.

The Brazilian public sector is the main buyer of pharmaceuticals, and thus, has enough purchasing power to set up its own list of pharmaceutical products to address the country's burden of disease. Health priorities have been set and should be used as guidelines by public and private organizations and non-governmental organizations (NGOs) to manage R\&D; for example, in producing new drugs with antimicrobial action or anti-HIV properties, or to treat leishmaniasis, schistosomiasis, malaria, and tuberculosis. The private pharmaceutical industry should adhere to established health priorities, targeting R\&D initiatives that can meet the country's public health needs.

A considerable amount of new knowledge has become available in the basic sciences, but transforming it into new drugs has been a frustrating, time-consuming, and expensive endeavor. Difficulties in discovering new drugs must not interfere with approval standards. Though drug R\&D and approval processes are decades old, they are not old-fashioned.

We propose that health priorities should be implemented, and continuously managed, so that their evolution and changes can be addressed over time. As the health authorities who evaluate new drugs are in a privileged position to monitor and detect these aspects, we consider that they must be responsible for this task. Developing countries have to acquire expertise in R\&D and develop knowledge and technology to build up their capacity in innovation and production of the drugs they actually need. The key elements to these achievements involve the setting up of health priorities and the implementation of effective management. 


\section{REFERENCES}

1. Lima NT, Gerschman S, Edler FC, Suárez JM (orgs). Saúde e democracia: história e perspectivas do SUS. Rio de Janeiro: Fiocruz; 2005.

2. Organização Pan-Americana da Saúde, Ministério da Saúde. Avaliação da Assistência Farmacêutica no Brasil. Brasília: OPAS; 2005.

3. Prata PR. Desenvolvimento econômico, desigualdade e saúde. Cad Saude Publica. 1994; 10(3):387-91

4. Schramm JMA, Oliveira AF, Leite IC, Valente JG, Gadelha AMJ, Portela MC, et al. Transição epidemiológica e o estudo de carga de doenças no Brasil. Ciênc Saúde Coletiva. 2004;9(4): 897-908.

5. Brasil, Ministério da Saúde. Doenças de notificação obrigatória. Available from: http:// portal.saude.gov.br/portal/saude/visualizar texto. $\mathrm{cfm} ? \mathrm{idtxt}=25340$. Accessed 25 August 2007.

6. Brasil, Ministério da Saúde, Secretaria de Atenção à Saúde, Departamento de Atenção Básica. Hipertensão arterial sistêmica para o Sistema Único de Saúde. Brasília: MS; 2006.

7. Brasil, Ministério da Saúde, Secretaria de Atenção à Saúde, Departamento de Atenção Básica. Hipertensão arterial. Available from: http://portal.saude.gov.br/portal/saude/ visualizar_texto.cfm?idtxt=23616. Accessed 20 April 2007.

8. Brasil, Ministério da Saúde, Secretaria de Atenção à Saúde, Departamento de Atenção Básica. Diabetes Mellitus. Brasília: MS; 2006.

9. Brasil, Ministério da Saúde, Secretaria de Atenção à Saúde, Departamento de Atenção Básica. Política nacional de atenção básica. Brasília: Ministério da Saúde; 2006.

10. Galvão J. A política brasileira de distribuição e produção de medicamentos anti-retrovirais: privilégio ou um direito? Cad Saude Publica. 2002;18(1):213-9.

11. Geremias SA. Conhecimento de políticas farmacêuticas de gerentes da rede de atenção básica do SUS no município de São Paulo [dissertação]. São Paulo: Programa de PósGraduação em Ciências da Coordenadoria de Controle de Doenças do Estado de São Paulo; 2007.

12. Brasil, Ministério da Saúde. Política Federal de Assistência Farmacêutica 1990 a 2002. Brasília: MS; 2002

13. Molinari GJDP, Moreira PCS, Conterno LO. A influência das estratégias promocionais das indústrias farmacêuticas sobre o receituário médico na Faculdade de Medicina de Marília: uma visão ética. Rev Bras Educ Méd. 2005; 29(2):110-8.

14. Pachelli CA. A propaganda de medicamentos e prática da automedicação no Brasil. Rev Adm Pública. 2003;37(2):409-25.

15. Brasil, Ministério da Saúde. Portaria n ${ }^{\circ} 3916$, de 30 de outubro de 1998 (DOU 10/11/1998). Institui a Política Nacional de Medicamentos.

16. Brasil, Ministério da Saúde, Secretaria de Ciência Tecnologia e Insumos Estratégicos. Relação nacional de medicamentos essenciaisRename. 4a. ed. Brasília: MS; 2006.

17. Brasil. Lei ${ }^{\circ} 9782$, de 26 de janeiro de 1999 (DOU 27/01/1999). Define o Sistema Nacio- nal de Vigilância Sanitária e cria a Agência Nacional de Vigilância Sanitária.

18. Schenkel E, Rech N, Farias M, Santos R Simões C. Assistência farmacêutica. In: Brasil, Ministério da Saúde, ed. Saúde no Brasil Contribuições para a agenda de prioridades de pesquisa. Brasília: MS; 2004. Pp. 199-219.

19. Centro de Gestão e Estudos Estratégicos. Formação de recursos humanos para a área farmacêutica: novas drogas e patentes. CGEE 2003.

20. Bermudez JZ, Bonfim JRA, eds. Medicamentos e a reforma do setor saúde. São Paulo: Hucitec-Sobravime; 1999

21. Federação Brasileira da Indústria Farmacêutica. A indústria farmacêutica no Brasil. São Paulo: Febrafarma; 2004

22. Takahashi VP. Transferência de conhecimento tecnológico: estudo de múltiplos casos na indústria farmacêutica. Gestão \& Produção. 2005;12(2):255-69.

23. Brasil, Ministério do Desenvolvimento Indústria e Comércio Exterior e Instituto Euvaldo Lodi. O futuro da indústria de fármacos no Brasil: coletânea de artigos. Brasília: MDIC/ IEL; 2004.

24. Brasil, Ministério do Desenvolvimento Indústria e Comércio Exterior e Ministério da Saúde. Fórum de competitividade da cadeia produtiva farmacêutica 2003-2006: o desafio a prosseguir. Brasília: MDIC; 2006.

25. Barberato Filho S. Pesquisa e desenvolvimento de fármacos no Brasil: estratégias de fomento [tese]. São Paulo: Universidade de São Paulo; 2006.

26. Vidotti CCF. Medicamentos novos e as necessidades do Sistema Único de Saúde: políticas públicas para pesquisa e desenvolvimento de fármacos no Brasil [tese]. Brasília: Universidade de Brasília; 2007.

27. Brasil, Ministério da Saúde, Conselho Nacional de Saúde. Conferência Nacional de Medicamentos e Assistência Farmacêutica (1:2003). Relatório Final. Brasília: MS, 2005.

28. Kaitin KI, Healy EM. The new drug approvals of 1996, 1997, and 1998: Drug development trends in the user fee era. Drug Inf J. 2000;34: 1-14.

29. Trouiller P, Olliaro P, Torreele E, Orbinski J, Laing R, Ford N. Drug development for neglected diseases: a deficient market and a public-health policy failure. Lancet. 2002;359: 2188-94.

30. Ghosh A, Hazra A, Mandal SC. New drugs in India over the past 15 years: Analysis of trends. Natl Med J India. 2004;17(1):10-6.

31. WHO Collaborating Centre for Drugs Statistics Methodology. Anatomical therapeutic chemical-ATC classification. Available from: http://www.whocc.no/atcddd/. Accessed 6 June 2005

32. Food and Drug Administration, Center for Drug Evaluation and Research. Available from http://www.fda.gov/cder/rdmt/default. $\mathrm{htm}$. Accessed 17 July 2005

33. Brasil, Ministério da Saúde. Datasus. Available from: http://tabnet.datasus.gov.br/ tabnet/tabnet.htm. Accessed 9 September 2007.
34. Brasil, Ministério da Saúde, Departamento de Atenção Básica. Casos notificados de hanseníase no período de 1980 a 2003. Available from: http://portal.saude.gov.br/portal/saude/ visualizar_texto.cfm?idtxt=21643. Accessed 25 October 2006

35. Brasil, Ministério da Saúde. Doenças infecciosas e parasitárias: guia de bolso. $6^{\mathrm{a}}$ ed. ampl. Brasília: MS; 2006

36. Brasil, Ministério da Saúde. Saúde Brasil 2005: uma análise da situação de saúde no Brasil. Brasília: MS; 2005.

37. Food and Drug Administration. Innovation or stagnation. Challenge and opportunity on the critical path to new medical products. Washington(DC): FDA; 2004.

38. World Health Organization. Priority medicines for Europe and the World. Geneve: WHO; 2004.

39. Romano L, Silva M, Azevedo P. Análise de desempenho econômico-financeiro do setor farmacêutico no Brasil: 1998 a 2003. São Paulo: Febrafarma; 2005.

40. Dukes M. WHO and priority medicines: some notes in the margin. In: Seminar medicines for Europe and the world-setting priorities, missing the point; 2004 Nov 18; The Hague Amsterdam: Health Action International 2004.

41. Health Action International Europe. Running on empty: Medicine's production and the absence of innovation. Amsterdam: HAI; 2004.

42. Dukes M. Priority medicines and the world. Bull World Health Organ. 2005;83(5):324. Editorial.

43. Ministério da Saúde. Série Histórica de Casos e Óbitos de Doenças de Notificação Compulsória-Brasil, 1985 a 2005. Brasília: MS; 2006.

44. Brasil, Ministério da Saúde, Secretaria de Políticas de Saúde, Departamento de Atenção Básica, Gerência Técnica de Assistência Farmacêutica. Relatório de Gestão. Brasília: MS; 2002.

45. Brasil, Ministério da Saúde, Programas Estratégicos: Tuberculose. Available from: http:// portal.saude.gov.br/portal/saude/visualizar texto.cfm?idtxt=25311. Accessed 20 February 2008.

46. Rede Interagencial de Informações para a Saúde. Indicadores Básicos de Saúde no Brasil: Conceitos e Aplicações. Brasília: OPAS; 2002.

47. Costa JG, Santos AC, Rodrigues LC, Barreto ML, Roberts JA. Tuberculose em Salvador: custos para o sistema de saúde e para as famílias. Rev Saude Publica. 2005;39(1):122-8.

48. Agência Nacional de Vigilância Sanitária (Anvisa). Alerta SNVS/Anvisa/Ufarm n. 5, de $1^{\circ} / 10 / 2004$ Vioxx $^{\circledR}$ [rofecoxibe]-Retirado do mercado mundial por riscos cardíacos. Available from: www.anvisa.gov.br. Accessed 10 February 2005

49. Remme J, Blas E, Chitsulo L, Desjeux P, Engers $\mathrm{H}$, Kanyok T, et al. Strategic emphasis for tropical diseases research: a TDR perspective. Trends parasitol. 2002;18(10):421-6.

50. Mrazek M, Mossialos E. Stimulating pharmaceutical research and development for neglected diseases. Health policy. 2003;64:75-88. 
51. International Society of Drug BulletinsISDB. Declaração da ISDB sobre o Avanço Terapêutico no Uso de Medicamentos. Available from: http://www.isdbweb.org/pag/port. php. Accessed 15 May 2006.

52. Chaves GC, Oliveira MA, Hasenclever L, Melo LM. A evolução do sistema internacional de propriedade intelectual: proteção patentária para o setor farmacêutico e acesso a medicamentos. Cad Saúde Pública. 2007; 23(2):257-67.

53. Trouiller P, Olliaro P. Drug development output from 1975 to 1996: What proportion for tropical diseases? Int J Infect Dis. 1999;3:61-3. Editorial.
54. Croghan T, Pittman P. The medicine cabinet: What's in it, why, and can we change the contents? Health Aff. 2004;23(1):23-33.

55. Marques MB. Patentes farmacêuticas e acessibilidade aos medicamentos no Brasil. Hist Cien Saúde-Manguinhos. 2000;7(1):7-21.

56. Albuquerque EM, Souza S, Boessa A. Pesquisa e inovação em saúde: uma discussão a partir da literatura sobre economia da tecnologia. Ciênc Saúde Coletiva. 2004;9(2):277-94.

57. Morel CM, Acharya T, Broun D, Dangi A Elias C, Ganguly NK, et al. Health innovation networks to help developing countries address neglected diseases. Science. 2005; 309(5733):401-4.
58. Médecins Sans Frontiéres. Drugs for Negletected Diseases Working Group. Fatal Imbalance: The Crisis in Research and Development for Drugs for Neglected Diseases. Geneva: MSF; 2001.

Manuscript received on 16 May 2006. Revised version accepted for publication on 9 April 2008.

RESUMEN Objetivos. Describir los nuevos medicamentos lanzados al mercado en Brasil durante el período 2000-2004, comparar su descripción con la carga de enfermedades del país y recomendar iniciativas que permitan enfrentar la situación desde la perspectiva de un país en desarrollo.

\section{Nuevos medicamentos en Brasil: ¿responden a las necesidades de la salud pública brasileña?}

Palabras clave
Métodos. Se buscaron los nuevos medicamentos en una base de datos oficial de registro de medicamentos. Los nuevos medicamentos se categorizaron según la Clasificación Química Anatómico-Terapéutica (ATC), su indicación y su grado de innovación, y se compararon con las necesidades según la carga de enfermedades del país. Los datos de morbilidad y mortalidad de cuatro enfermedades seleccionadas (diabetes, enfermedad de Hansen, hipertensión y tuberculosis) se tomaron de documentos oficiales y de la literatura.

Resultados. En el período investigado se lanzaron al mercado 109 nuevos medicamentos. La mayoría eran antibióticos generales de uso sistémico (19), seguidos de antineoplásicos y agentes inmunomoduladores (16). El número de medicamentos nuevos lanzados en 2004 fue aproximadamente una tercera parte de los lanzados en 2000. De 65 nuevos medicamentos, solamente una tercera parte puede considerarse innovadora. La mayoría de los nuevos medicamentos estaban dirigidos a tratar enfermedades no infecciosas que por lo general afectan a los países industrializados y que constituyen una pequeña parte de los problemas que aquejan a Brasil.

Conclusiones. No hay correspondencia entre las necesidades de salud pública de Brasil y los nuevos medicamentos lanzados al mercado en ese país. No solamente disminuyó el número de nuevos medicamentos en el período estudiado, sino que solo unos pocos eran realmente nuevos en términos terapéuticos. Los países en desarrollo deben ganar experiencia en investigación y desarrollo para fortalecer su capacidad de innovar y producir los medicamentos que necesitan.

Medicamentos nuevos, medicamentos de interés en salud pública, comercialización de medicamentos, innovación, farmacoepidemiología, Brasil. 